\title{
ERGONOMI PARTISIPASI DALAM MEMPREDIKSI TINGKAT KESEDIAAN UNTUK PERUBAHAN KUALITAS HIDUP KELUARGA TUKANG SAMPAH/ PEMULUNG
}

\author{
Helena J Kristina*), Agustina Christiani, Ishak, Meli Puspitasari \\ Program Studi Teknik Industri, Universitas Pelita Harapan, Tangerang, Indonesia
}

(Received: February 15, 2016 / Accepted: July 06, 2017)

\begin{abstract}
Abstrak
Bintara - Bekasi adalah salah satu wilayah dimana sampah menjadi sumber material bagi kelangsungan hidup keluarga yang tinggal di sekitar Bintara. Masyarakat yang tinggal di sana kurang lebih ada $200 \mathrm{KK}$. Lapak ini dikelola oleh 10 bos lapak, dengan status sewa tempat untuk menampung sampah. Setiap bos membawahi 17 KK sampai 20 KK. Pekerjaan mereka adalah pemulung dan penarik sampah di rumah-rumah penduduk. Tipe penelitian adalah penelitian eksperimen, dikarenakan datanya belum pernah ada, dan harus diciptakan terlebih dahulu. Hasil penelitian ini, diharapkan akan berguna untuk mengembangkan inovasi-inovasi yang berguna dalam meningkatkan kualitas hidup masyarakat penghuni lapak sampah. Partisipan yang ikut ada 14 keluarga yang semuanya berprofesi sebagai pemulung selama 5 tahun lebih di lapak sampah 1 Bintara. Alat ukur kuesioner 1 untuk mengukur sikap, niat dan keinginan untuk perubahan kualitas hidup, disusun dengan pendekatan Theory of Reasoned Action. Alat ukur kuesioner 2 untuk memprediksi tingkat pengetahuan, orientasi dan motivasi partisipan. Tema edukasi bagian 1 yang diberikan terdapat empat modul, yaitu lubang resapan biopori, pembuatan kompos dan MOL, ketrampilan tangan daur ulang, dan penanaman bibit sayur dalam wadah bekas. Materi edukasi 2 disampaikan dalam bentuk skenario cerita yang meliputi: konsep lapak sampah hijau: bersama merawat lapak yang menjadi sumber ekonomi keluarga, bersama merawat lingkungan di sekitar lapak untuk kesehatan bersama, dan bersama merawat sikap saling menyapa, menghormati, mau mendengarkan, mau belajar untuk kemajuan diri, mau bekerjasama dan mau terbuka untuk kebaikan bersama, konsep K3 (kesehatan dan keselamatan kerja) selama bekerja di lapak sampah dan konsep pemilahan sampah organik dan nonorganik sejak dari rumah penduduk. Penerapan ini dapat dikatakan berhasil karena para peserta mau mengikuti proses edukasi dan mau terlibat. Secara keseluruhan, sikap niat dan perilaku dari partisipan terhadap kegiatan edukasi tergolong dalam kategori sangat positif, walaupun terdapat penurunan nilai pada hasil pengukuran akhir. Penurunan nilai dipengaruhi oleh proses edukasi yang telah dilakukan, karena partisipan merasa sulit untuk mempraktekkannya dalam keseharian hidup, agak malas dan butuh tenaga lebih untuk mewujudkannya, kondisi udara serta lingkungan yang membuat partisipan cepat merasa lelah. Partisipan mempunyai latar belakang keluarga besar mereka adalah petani garapan di Karawang dan Indramayu, dimana hidup sebagai petani garapan adalah sangat jauh lebih sulit mendapat penghasilan yang layak. Mereka mengatakan bahwa menjadi pemulung dan tukang sampah lebih berhasil secara ekonomi untuk kehidupan mereka, sehingga mereka tidak terlalu menginginkan kembali mengeluti pekerjaan yang berhubungan dengan mengolah tanah dan tanaman.
\end{abstract}

Kata Kunci : ergonomi partisipasi, lapak sampah, eksperimen edukasi, keluarga tukang sampah/ pemulung, kesediaan untuk perubahan kualitas hidup

\begin{abstract}
Bintara - Bekasi is one area where garbage becomes a source of living for people staying in that area. There are approximately 200 families living in

*) Penulis Korespondensi. Bintara traditional material recovery site. This email: helena.kristina@uph.edu facility is managed by 10 bosses, who rent land to
\end{abstract}


collect trash. Each boss manages 17 -20 families. Their main jobs are scavengers and trash collectors in the neighbourhood area. The type of this research is experimental research, because there are no available data yet so that data have to be created first. The result of this research can be used to develop innovation in order to increase the quality of life of the trash collectors community.Total participants are 14 families who have been working as scavengers for more than 5 years in Bintara. The first questionnaires were developed to measure attitude, intention and behavior to have a changing quality of life, based on the theory of reasoned action. The second questionnaires were developed to predict the level of knowledge, orientation and motivation of participants. The first part of education theme consisted of four modules: biopore absorption hole, making compost and local microorganism, handicraft from recycled materials and planting vegetable seed in used plastic container. The second education materials are delivered into several scenarios, including: together nurturing the material recovery site as the economic source of families, together nurturing the surrounding environment for the health of community, together maintaining good attitude (greet and respect each other, willingness to listen, eagerness to learn, willingness to cooperate, and openess), occupational safety and health as well as the concept of separating organic and inorganic waste at the source. The implementation of these modules was quite successful because the participants were willing to follow the education process and participate actively. Overall, the attitude, intention and behavior of the participants on education process were strongly positive, although there were decreasing score on the final measurement. The decreasing score was influenced by the education process that has been conducted before, because some participants were facing difficulties in implementing the education materials in their daily lives, they were reluctant due to extra energy needed to implement it, and the hot environment that makes them feel tired rapidly. The family background of the participants were farm workers in Karawang and Indramayu, where they thought farm workers were more difiicult to make a living. They considered that being scavengers and trash collectors gave them more economic benefit, so that they do not want to do any more work related to cultivate soils and planting crops.

Keywords : participatory ergonomics, traditional material recovery site, educational experiment scavengers family, willingness to have a change in quality of life

\section{Pendahuluan}

Kemampuan manusia beradaptasi berbeda-beda tergantung kepribadian dan situasi, dan setiap orang juga memiliki kekurangan tertentu. Komunitas sebagai pengelompokan sosial paling instan yang lebih besar daripada keluarga atau sekedar pertemanan, unit spasial yang kecil dan relatif homogen dan dengan pandangan-pandangan yang hampir sama, serta dapat membentuk suatu konteks yang penting bagi konservasi kualitas lingkungan hidup. Komunitas tidak hanya didasarkan pada satu lokasi yang sama, tetapi bisa juga terbentuk karena suatu kepentingan, minat, nilai atau profesi. Komunitas juga selalu memiliki banyak kepentingan dan pelaku, dan berkaitan dengan entitas entitas lain dalam skala yang berbeda (Clayton Susan \& Gene Myers, 20140).

Komunitas penghuni lapak sampah, biasanya terdiri dari kepala pemulung/ tukang sampah dan membawahi beberapa keluarga yang berprofesi sebagai pemulung dan tukang sampah. Sumber mata pencaharian mereka tidak lain adalah sampah yang dibuang oleh masyarakat. Sampah yang dapat didaur ulang adalah sampah anorganik yang masih memiliki nilai ekonomis yang tinggi. Nilai jual sampah pada umumnya adalah hasil kali volume timbunan per jenis sampah yang didapat dengan harga jual per jenis sampah. Semakin besar volume timbulan sampah di suatu lapak sampah, maka ada kemungkinan kegiatan $3 \mathrm{R}$ juga semakin besar. Besarnya harga jual sampah dipengaruhi oleh jenis sampah yang dapat didaur ulang. Harga jual ditiap lapak berubah-ubah tergantung dengan permintaan pasar.

Bintara - Bekasi adalah salah satu wilayah dimana sampah menjadi sumber material bagi kelangsungan hidup keluarga yang tinggal disekitar Bintara. Masyarakat yang tinggal disana kurang lebih ada 200 KK. Lapak ini dikelola oleh 10 bos lapak, dengan status sewa tempat untuk menampung sampah. Setiap bos membawahi 17 KK sampai 20 KK. Kisaran umur orang yang tinggal di daerah ini, mulai dari bayi sampai dengan lansia. Anak - anak dan remaja di sana, setelah pulang sekolah juga membantu mencari sampah yang dapat dijual. Kondisi lingkungan hidup di Lapak Sampah Bintara Bekasi amat memprihatinkan. Warga penghuni lapak sampah, kurang memperhatikan dampak dari sisi kesehatan dan lingkungan hidup akan timbunan sampah yang mereka kumpulkan sebagai tempat untuk mencari nafkah dan sumber ekonomi keluarga. Adapun kondisi saat ini, ada 10 bos di lapak sampah 
Bintara Bekasi, yang masing-masing mempunyai daerah operasinya sendiri.

Ergonomi partisipasi menekankan pemanfaatan potensi manusia pekerja untuk melakukan perbaikan ergonomis di tempat kerjanya. Pada tingkat yang paling sederhana, ergonomi partisipasi mengajarkan kesadaran untuk bisa melihat dan merasakan bahwa kontribusi pekerja adalah benar diperlukan. Partisipasi merupakan terlibatnya orang secara mental dan emosional di dalam satu komunitas yang merangsang mereka untuk berkontribusi kepada tujuan kelompok dan berbagi tanggung jawab untuk apa yang dihasilkannya (Manuaba, 1999). Tingkat pendekatan dalam ergonomi partisipasi adalah agar orang mampu untuk melakukan sendiri karena sudah mendapat latihan. Ergonomi partisipasi memerlukan kondisi tertentu untuk bisa berlangsung secara berhasil dan sukses yaitu adanya waktu yang cukup untuk ikut terlibat, manfaat yang diperoleh lebih besar dari pada biaya yang dikeluarkan, dan relevan dengan kebolehan orang yang dilatih untuk menangani masalah, serta cukup waktu berkomunikasi, cara berkomunikasi yang menguntungkan kedua belah pihak, tidak adanya perasaan dipaksa oleh pihak lain dan masih berada dalam wilayah kebebasan bekerja.
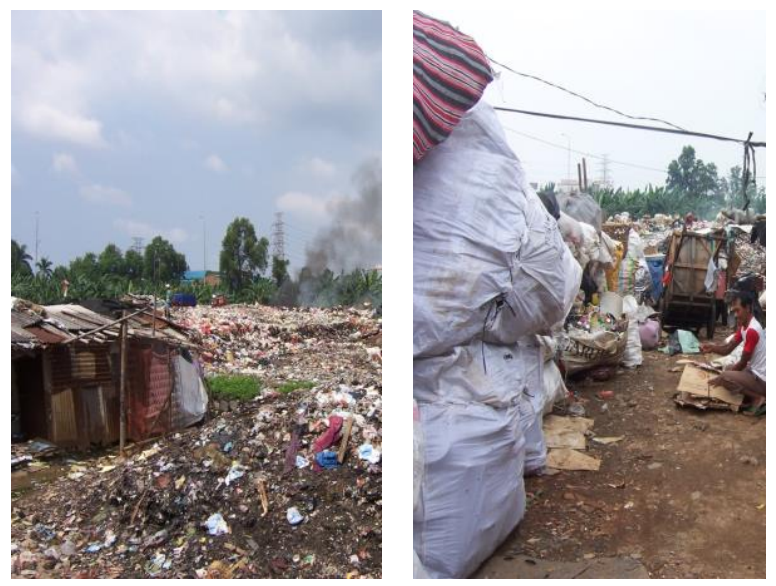

Gambar 1. Keadaan Lapak Sampah Bintara Bekasi

Partisipasi merupakan terlibatnya orang secara mental dan emosional di dalam satu kelompok atau komunitas yang merangsang mereka untuk berkontribusi kepada tujuan kelompok dan berbagai tanggung jawab untuk apa yang dihasilkannya (Manuaba, 1999). Melalui ergonomi partisipasi, diharapkan seluruh peserta memiliki keterlibatan langsung dalam perencanaan dan pelaksanaan tugastugas mereka, seperti adanya rapat yang bertujuan untuk saling bertukar pikiran maupn menyumbangkan ide-ide yang dapat digunakan untuk menyelesaikan tugas dengan baik dan sempurna (Vink et.all, 2008).
Dalam penelitian ini, akan dilakukan eksperimen didaktik dengan pendekatan konsep ergonomi partisipasi guna mengukur seberapa besar keinginan warga melakukan perubahan terhadap kualitas hidup di lapak sampah tempat mereka tinggal. Setelah selesai berpartisipasi, mereka akan mendapatkan tabungan partisipasi per keluarga sesuai dengan usaha yang mereka keluarkan. Tabungan tersebut akan dikelola oleh wakil warga lapak sampah yang dibina Biro Pelayanan Masyarakat Lembaga Daya Dharma KAJ melalui tabungan mini koperasi saudara makmur (MISI SAMA).

\section{Materi dan Metode Penelitian}

Tipe penelitian adalah penelitian eksperimen, dikarenakan datanya belum pernah ada, dan harus diciptakan terlebih dahulu. Hasil penelitian ini, diharapkan akan berguna untuk mengembangkan inovasi-inovasi yang berguna dalam meningkatkan kualitas hidup masyarakat penghuni lapak.

\subsection{Deskripsi Partisipan}

Tukang sampah/ pemulung di lapak sampah 1 Bintara Bekasi milik Bapak Darman, di sini terdapat 17 kepala keluarga yang semuanya berprofesi sebagai pemulung selama 5 tahun lebih di lapak sampah Bintara. Adapun tingkat pendidikan partisipan adalah tidak pernah sekolah sampai tingkat SD. Kepala keluarga yang berprofesi sebagai pemulung dan tukang sampah mulai mengambil sampah di rumah warga sekitar lapak mulai dari jam 3 siang hingga jam 5 sore. Sedangkan, ibu-ibu membantu para suami dengan memilah sampah pada pagi hari ataupun sore hari dengan tujuan menghindari panasnya terik matahari pada siang hari. Selain membantu memilah sampah, banyak ibu-ibu yang bekerja sambilan sebagai jasa cuci gosok baju. Sebelum tinggal di lapak sampah Bintara, penghuni lapak adalah generasi yang sebelumnya berprofesi sebagai petani dan sebagian besar berasal dari Karawang dan Indramayu. Banyak yang meninggalkan pekerjaan mereka sebagai petani garapan karena pendapatan yang diperoleh tidak menentu, hal ini menyebabkan generasi sebelum mereka harus meminjam uang untuk mencukupi kebutuhan sehari-hari. Sebaliknya bekerja di lapak sampah Bintara ini lebih terjamin karena selalu mendapat pemasukan setiap harinya. Alasan inilah yang membuat para penghuni lapak sampah Bintara ini betah untuk bekerja dan tinggal di sana.

\subsection{Peralatan}

Alat ukur kuesioner 1 (pre tes dan post tes), untuk mengukur sikap, niat dan keinginan untuk perubahan kualitas hidup, disusun dengan pendekatan Theory of Reasoned Action (Dharmmesta, 1998). Alat ukur ini 
diberikan pada grup partisipan edukasi (istri/ anak usia sekolah) dan control grup (suami/ tukang sampah yang tidak mengikuti edukasi secara langsung, tetapi mendapat informasi dari sang istri/ anak usia sekolah yang ikut edukasi). Pemberian alat ukur ini dilakukan sebelum edukasi dan setelah edukasi.Variabel yang diukur yaitu:

1) Beliefs that behavior leds to certain (bi) adalah kekuatan dari keyakinan bahwa melaksanakan perilaku b cenderung menimbulkan akibat i. Indikator-indikator pada variabel ini biasanya terdiri dari keuntungan, kerugian, serta konsekuensi dari yang dilakukan oleh seseorang.

2) Evaluation of the outcomes (ei) adalah evaluasi konsekuensi terhadap akibat i.

3) Beliefs that specific referents think I should or not should perform the behavior $(\mathrm{NBj})$ adalah keyakinan normatif seseorang terhadap referensi j untuk melakukan atau tidak melakukan perilaku B.

4) Motivation to comply with the specific referents $(\mathrm{MCj})$ adalah motivasi partisipan untuk menuruti pengaruh kelompok referensi j.

5) Attitude toward the behavior (Ab) adalah sikap partisipan terhadap melaksanakan sesuatu. Sikap ini memiliki dua komponen yaitu keyakinan terhadap konsekuensi perilaku dan kesesuaian penilaian positif dan negatif dari perilaku.
6) Subjective norm (SN) adalah norma subjektif individu yang berkaitan dengan apakah orang lain (referen) $\mathrm{j}$ berpendapat bahwa seseorang seharusnya melaksanakan perilaku B. Indikator pada variabel ini biasanya terdiri dari individu atau kelompok yang mendukung, menghambat, dan mempengaruhi perilaku seseorang.

7) Intention (BI) merupakan minat partisipan untuk melaksanakan perilaku B.

8) Behavior (B) adalah perilaku tertentu.

Alat ukur kuesioner 2: untuk memprediksi tingkat pengetahuan, orientasi dan motivasi partisipan. Indikatornya meliputi kemampuan mengingat, kemampuan penalaran dan kemampuan melihat keterkaitan antar materi. Pemberian alat ukur berupa angket A (sebelum edukasi), B (setelah edukasi) dan $\mathrm{C}$ (setelah pemberian pekerjaan rumah (PR), jangka waktu pengukuran 2 minggu sejak pemberian PR) untuk setiap topik edukasi guna mengukur kemampuan kognitif partisipan. Topik edukasi yang diberikan terdapat empat modul, yaitu lubang resapan biopori (topik 1), pembuatan kompos dan MOL (topik 2), ketrampilan tangan daur ulang (topik 3) dan penanaman bibit sayur dalam wadah bekas (topik 4). Adapun alat ukur dipergunakan gambar untuk memudahkan partisipan yang tidak bisa membaca dan menulis, sedangkan pertanyaan disebutkan dan dijelaskan oleh narator.

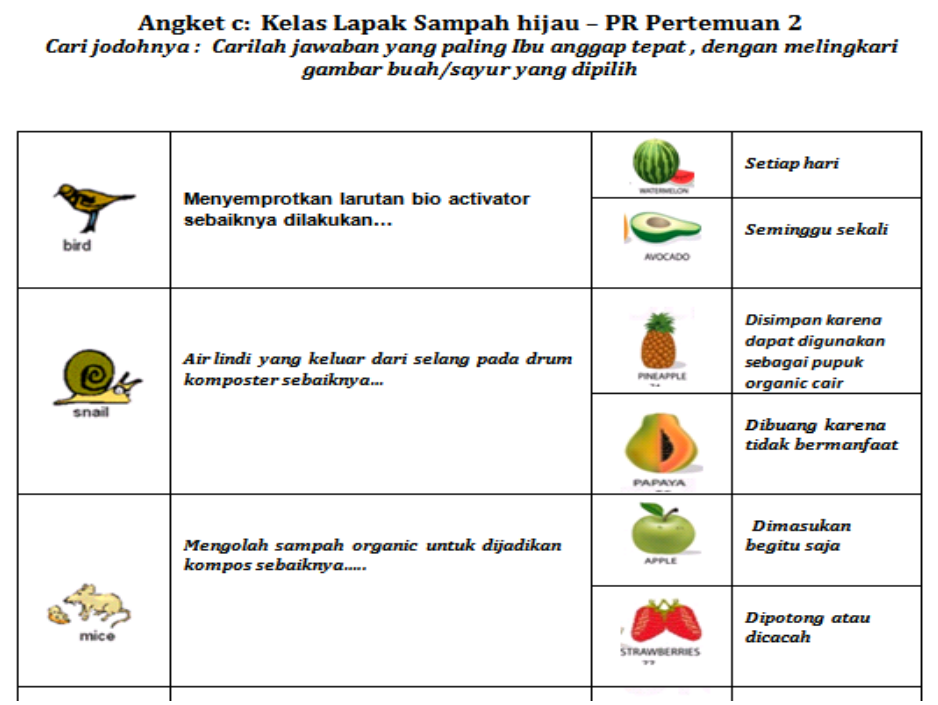

Gambar 2. Contoh Alat Ukur C pada Kuesioner 2

Materi didaktik disampaikan dalam bentuk skenario dan cerita, meliputi:

1) konsep lapak sampah hijau : bersama merawat lapak yang menjadi sumber ekonomi keluarga, bersama merawat lingkungan di sekitar lapak untuk kesehatan bersama, dan bersama merawat sikap saling menyapa, menghormati, mau mendengarkan, mau belajar untuk kemajuan 
diri, mau bekerjasama dan mau terbuka untuk kebaikan bersama.

2) konsep K3 (kesehatan dan keselamatan kerja) selama bekerja di lapak sampah

3) konsep pemilahan sampah organik dan nonorganik sejak dari rumah penduduk

Alat/ bahan penunjang/ partisipan eksperimen lainnya : checklist observasi selama kegiatan edukasi didaktik untuk pemeriksaan pekerjaan rumah dan kehadiran, daftar hadir sosialiasi edukasi selama eksperimen didaktik, tape untuk rekaman wawancara, $\mathrm{X}$ banner edukasi skenario cerita, alat K3 sederhana (sarung tangan, sepatu bot, masker), alat dan bahan untuk pengolahan kompos/ pembuatan pupuk MOL, bibit tanaman dan media tanah, sampah kemasan, sampah organik, pengajar ketrampilan daur ulang dari bank sampah Berlian Tangsel, tabungan partisipasi (tabel 1) : partisipan berhak mendapat nilai tabungan sesuai dengan partisipasi yang diberikannya, mulai dari tingkat kehadiran selama kelas edukasi sampai partisipasi mengerjakan pekerjaan rumah (kurun waktu 2 minggu), dan partisipasinya menerangkan pada suami mengenai materi edukasi (lewat form penilaian pendapat).

Tabel 1. Nilai Tabungan Partisipasi Kelas Lapak Sampah Bintara Bekasi

\begin{tabular}{|c|c|c|c|c|}
\hline $\begin{array}{l}\text { Pertemuan } 1 \\
\end{array}$ & Pertemuan 2 & Pertemuan 3 & Pertemuan 4 & Pertemuan 5 \\
\hline \multirow[t]{6}{*}{ Hadir : Rp 5.000 } & Hadir : Rp 5.000 & Hadir : Rp 5.000 & Hadir : Rp 5.000 & Hadir : Rp 5.000 \\
\hline & $\begin{array}{l}\text { Mengerjakan PR 1: } \\
\text { Rp } 5.000\end{array}$ & $\begin{array}{l}\text { Mengerjakan PR 2: } \\
\text { Rp 5.000 }\end{array}$ & $\begin{array}{l}\text { Mengerjakan PR 3: } \\
\text { Rp 5.000 }\end{array}$ & $\begin{array}{l}\text { Mengerjakan PR 4: } \\
\text { Rp 5.000 }\end{array}$ \\
\hline & & & & $\begin{array}{l}\text { Membawa kertas } \\
\text { penilaian/pendapat suami } \\
\text { dan anak: } \\
\text { Rp } 5.000\end{array}$ \\
\hline & & $\begin{array}{l}\text { Masih Mengerjakan } \\
\text { PR } 1 \text {. Rn } 10000\end{array}$ & $\begin{array}{l}\text { Masih Mengerjakan } \\
\text { PR 2. Rp } 10000\end{array}$ & $\begin{array}{l}\text { Masih Mengerjakan } \\
\text { PR 3. Rn } 10000\end{array}$ \\
\hline & & & $\begin{array}{l}\text { Masih Mengerjakan } \\
\text { PR 1: Rp } 10.000\end{array}$ & $\begin{array}{l}\text { Masih Mengerjakan } \\
\text { PR 2: Rp } 10.000\end{array}$ \\
\hline & & & & $\begin{array}{l}\text { Masih Mengerjakan } \\
\text { PR 1: Rp } 10.000\end{array}$ \\
\hline
\end{tabular}

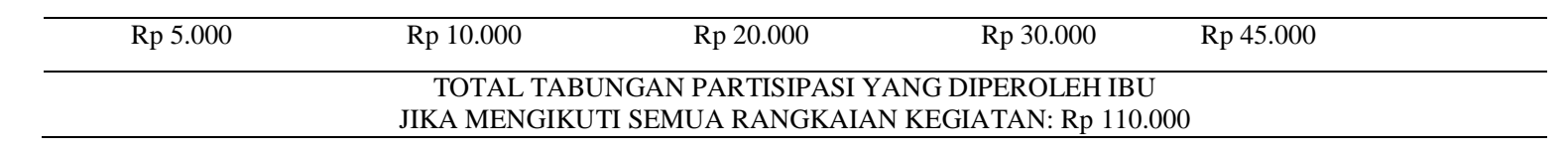

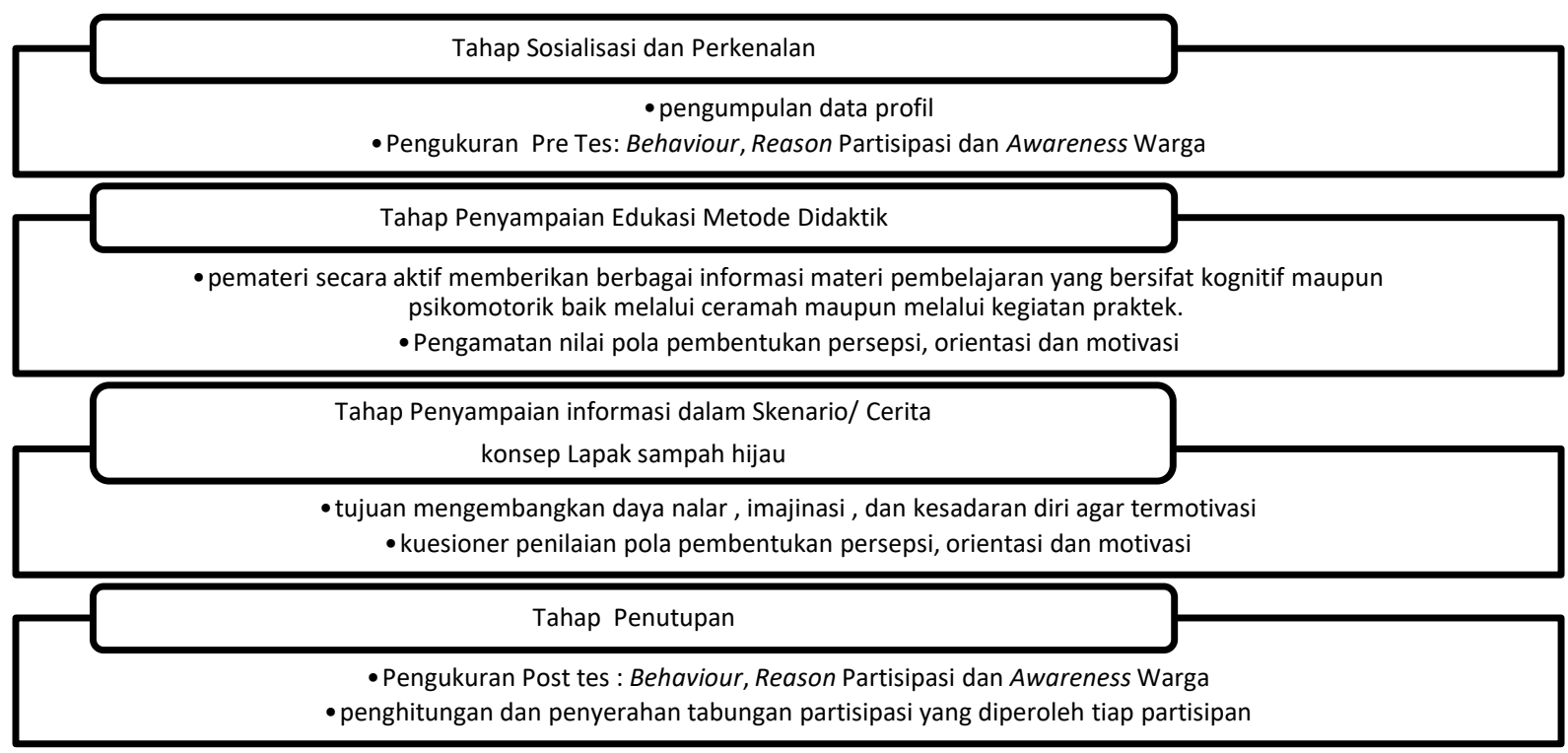

Gambar 3. Tahapan Eksperimen
2.3. Prosedur Eksperimen Didaktik dan Pengumpulan Data Penelitian
dan tema 1 dapat dilihat pada tabel 2. Pertemuan
Berikut (gambar 3) adalah urutan eksperimen, dilakukan pada hari Sabtu jam 13.00 sampai 15.00 setiap 2 minggu sekali sampai edukasi selesai. sedangkan rincian contoh alur proses pada pertemuan 
Tabel 2. Contoh Alur Proses Eksperimen Didaktik Pertemuan Tema 1 Menggunakan Pendekatan Konsep Ergonomi Partisipasi

Pertemuan 1:

Perkenalan dan sosialisasi rencana kegiatan kelas lapak sampah hijau dan nilai tabungan partisipasi kelas lapak sampah hijau yang akan diberikan di pertemuan ke -5

Materi skenario 1 : Konsep Lapak Hijau

Kuesioner A1

Angket 1a

Dengar pendapat

Edukasi 1 : Pembuatan Lubang Biopori untuk Kompos Organik Hewani/ Coklat

Praktek Pembuatan Lubang Biopori

Angket 1b

PR 1:

- Tiap keluarga diberikan pralon dan tutup lubang biopori

- Tiap keluarga dapat meminjam bergantian bor biopori di Ibu Sarni (ada 2 buah) untuk berlatih membuat lubang biopori di dekat rumahnya untuk membuat kompos

- $\quad$ Ceritakan pertemuan hari ini pada suami, berikan kuesioner B1 pada suami, dibawa saat pertemuan 2

\subsection{Hipotesis Penelitian yang Mau Diukur}

Ada 4 hipotesis penelitian yang dibuat:

1) Mengukur asosiasi antara tingkat kehadiran partisipan dengan tema edukasi :

Ho : Tidak terdapat hubungan antara variabel tingkat kehadiran partisipan dengan variabel tema pertemuan edukasi yang ditawarkan.

H1 : Terdapat hubungan antara variabel tingkat kehadiran peserta dengan variabel tema pertemuan edukasi yang ditawarkan.

2) Mengukur asosiasi hasil edukasi dari tiap pertemuan ( $\mathrm{i}=$ topik 1 sampai $\mathrm{j}=$ topik 4 ):

Ho : Tidak ada hubungan antara hasil edukasi ke-i dan hasil edukasi ke-j

H1 : Terdapat hubungan antara hasil edukasi ke-i dan hasil edukasi ke-j

3) Mengukur ada atau tidak perbedaan hasil pembelajaran/kemampuan kognitif tiap topik edukasi:

Ho : Semua edukasi memiliki hasil penilaian yang sama (identik).
H1 : Semua edukasi memiliki hasil penilaian yang berbeda (tidak identik).

4) Membandingkan hasil pengukuran sikap, norma dan perilaku untuk kontrol grup (suami/ayah) dengan grup partisipan (istri/anak):

Ho : Tidak terdapat perbedaan berarti pada sikap, norma dan perilaku kedua grup.

H1 : Terdapat perbedaan berarti pada sikap, norma dan perilaku kedua grup.

\section{Hasil dan Pembahasan}

Dari 17 keluarga, hanya 14 keluarga yang ikut sebagai partisipan. Berdasarkan eksperimen edukasi yang telah dilakukan, diperoleh beberapa data seperti tingkat kehadiran (tabel 3), jumlah soal yang dijawab benar dari alat ukur angket A (sebelum edukasi), angket B (setelah edukasi), dan angket C (evaluasi pekerjaan rumah) untuk setiap tema. 
Tabel 3. Daftar Kehadiran Peserta Eksperimen Didaktik/ Tema Edukasi (Satuan Keluarga)

\begin{tabular}{lcccc}
\hline & \multicolumn{4}{c}{ Tema Edukasi } \\
\cline { 2 - 5 } $\begin{array}{c}\text { Tingkat } \\
\text { Kehadiran } \\
\text { partisipan } \\
\text { (keluarga) }\end{array}$ & $\begin{array}{c}\text { Tema 1 Lubang } \\
\text { resapan biopori (LRB) } \\
\text { dan cara membuat } \\
\text { kompos dalam LRB }\end{array}$ & $\begin{array}{c}\text { Temb 2 } \\
\text { Tanam - Kompos } \\
\text { dengan Drum } \\
\text { Komposter }\end{array}$ & $\begin{array}{c}\text { Cara membuat tas } \\
\text { belanja dari sampah } \\
\text { ring gelas plastik }\end{array}$ & $\begin{array}{c}\text { Menanam Sayur } \\
\text { dalam Wadah } \\
\text { Bekas }\end{array}$ \\
\hline Hadir & 13 & 13 & 13 & 14 \\
\hline Tidak Hadir & 1 & 1 & 1 & 0 \\
\hline Total & 14 & 14 & 14 & 14 \\
\hline
\end{tabular}

Hasil pengukuran asosiasi untuk menguji apakah ada hubungan antara variabel tingkat kehadiran peserta dengan variabel tema edukasi, hasil ChiSquare Test didapatkan nilai Asymptotic Significance (2-tailed) lebih dari 0,05, yaitu 0,788 sehingga dapat disimpulkan bahwa tidak ada hubungan antara tingkat kehadiran partisipan dengan tema edukasi yang dibahas.

Pengujian selanjutnya mengukur asosiasi hasil edukasi tiap pertemuan ( $\mathrm{i}=$ topik 1 sampai $\mathrm{j}=$ topik 4 ), menggunakan Uji Kruskal-Wallis untuk mengukur apakah semua tema edukasi memiliki nilai yang identik atau sama. Dalam pengujian Kruskal-Wallis, digunakan nilai Confidence Interval sebesar $95 \%$. Berdasarkan pengujian yang dilakukan, didapatkan nilai Asymptotic Significance (2-tailed) sebesar 0,171 yang lebih besar dari 0,05, sehingga dapat disimpulkan bahwa dari semua tema edukasi yang diberikan memiliki nilai yang tidak berbeda secara signifikan, semua tema edukasi tidak memiliki hubungan antara edukasi ke-i dengan edukasi ke- j, atau bersifat independent.

Hal ini berarti partisipan kurang menyadari bahwa ada materi yang serupa/ mirip, dan menganggap semua materi adalah berbeda dan tidak ada saling keterkaitan. Bahwa dari ketiga tema edukasi yang diberikan yaitu lubang resapan biopori, pembuatan kompos dengan komposter, dan ketrampilan tangan, semuanya memiliki penilaian yang sama atau identik, yang berarti ketiga edukasi ini memiliki bobot atau tingkat kesulitan yang sama dan tidak ada keterkaitan satu dengan yang lainnya dimata peserta. Sehingga pembelajaran selalu kembali ke titik awal.

Hasil pembelajaran/kemampuan kognitif tiap topik edukasi dilakukan menggunakan uji Wilcoxon. Didapatkan nilai Asymptotic Significance (2-tailed) sebesar 0,007, lebih kecil dari 0,05 yang artinya terdapat perubahan nilai yang signifikan akan pemahaman materi sebelum dan sesudah edukasi. Untuk aspek pengetahuan, peserta edukasi masih memiliki pengetahuan yang minim mengenai materi yang disampaikan sebelum edukasi dilakukan (angket A). Setelah edukasi hasil pengukuran tingkat pengetahuan partisipan didapatkan bahwa nilai pengetahuan partisipan mengalami peningkatan sesudah edukasi (angket B). Peningkatan nilai ini menandakan bahwa partisipan cukup menyimak materi yang diberikan dan mampu mengingatnya, sehingga mereka dapat menjawab pertanyaan dengan benar. Hal ini menunjukan bahwa edukasi yang diberikan dapat berpengaruh terhadap perkembangan pengetahuan dan wawasan partisipan. Namun penurunan nilai terjadi pada penilaian angket $\mathrm{C}$ (setelah partisipan diberi waktu 2 minggu untuk mengerjakan pekerjaan PR praktek dan penilaian tingkat pengetahuan partisipan diambil ulang). Hal ini disebabkan banyak partisipan yang lupa mengenai materi edukasi yang sudah diberikan, tidak mengulang sendiri (tugas rumah praktek dikerjakan suami), dan karena tidak membaca ulang materi edukasi yang disampaikan karena kesibukannya. Pada Gambar 4 dapat dilihat proses edukasi mengenai tema $\mathrm{K} 3$ dan tema ketrampilan tangan daur ulang.

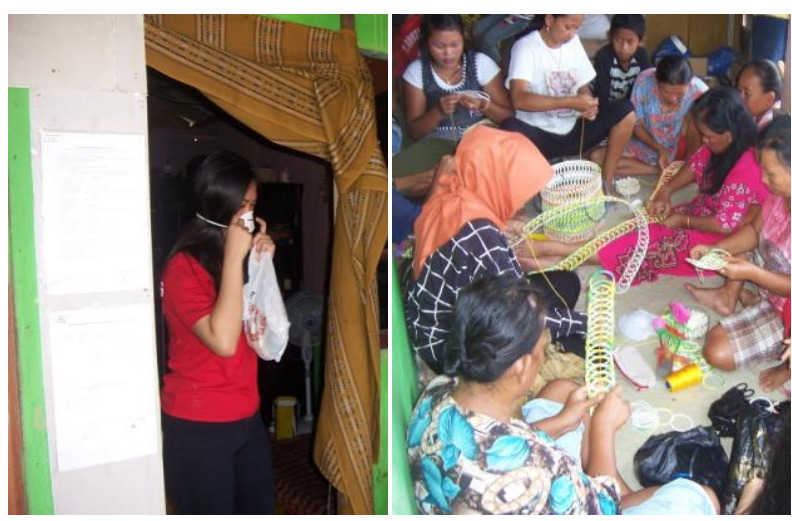

Gambar 4. Proses Edukasi Mengenai Topik K3 dan Topik Ketrampilan Tangan Daur Ulang

Untuk pengukuran sikap, niat dan perilaku warga dengan theory of reasoned action, terdiri dari 6 faktor, yaitu perilaku sikap untuk ikut dalam kepengurusan pada kegiatan mewujudkan lapak sampah hijau $\left(\mathrm{PSN}_{1}\right.$ dan $\left.\mathrm{PSN}_{2}\right)$, norma subjektif 
warga terhadap partisipasi kegiatan mewujudkan lapak sampah hijau $\left(\mathrm{NSN}_{1}\right.$ dan $\left.\mathrm{NSN}_{2}\right)$ dan niat berperilaku warga untuk berpartisipasi pada kegiatan mewujudkan lapak sampah hijau $\left(\mathrm{NPN}_{1}, \mathrm{NPN}_{2}\right)$. Setiap faktor tersebut dikategorikan menjadi sangat positif, positif, netral, negatif dan sangat negatif. Alat ukur diberikan pada awal pertemuan dan akhir pertemuan edukasi, baik untuk partisipan eksperimen (istri/anak) dan control grup (suami). Indikatorindikator variabel sudah lolos uji validitas, uji realibilitas, yang kemudian dilanjutkan dengan uji dua data saling berhubungan. Hasil pengukuran didapatkan 4 faktor yang memiliki kategori "Sangat Positif" dan terdapat 2 faktor yang memiliki kategori "Positif". Hal ini menunjukan bahwa para partisipan memiliki tanggapan yang positif terhadap kegiatan mewujudkan lapak sampah hijau. Hal ini terutama dikarenakan adanya insentif berupa uang tabungan partisipasi. Hasil pengukuran sikap, norma dan perilaku untuk kontrol grup (suami partisipan) dengan grup partisipan (istri/anak) diuji dengan menggunakan Uji Wilcoxon untuk melihat adakah perbedaan secara signifikan, dengan menggunakan confidence interval sebesar 95\%. Didapatkan nilai Asymptotic Significance (2-tailed) sebesar 0,060, lebih besar dari 0,05 yang artinya tidak terdapat perbedaan atau peningkatan pada nilai rata-rata sikap, norma dan perilaku sebelum dilakukan edukasi dan sesudah dilakukan edukasi untuk kedua grup.

Hasil Uji Wilcoxon menunjukan bahwa sikap, niat dan perilaku partisipan (istri/ anak) berkurang setelah mengikuti proses edukasi. Hal ini terjadi, dikarenakan partisipan sudah merasakan sulitnya dan besarnya usaha untuk mewujudkan konsep lapak sampah hijau. Terlihat bahwa perubahan terbanyak adalah perubahan secara negatif, dengan jumlah negative ranks sebanyak 13 orang. Untuk partisipan control group (suami/ ayah) juga terlihat bahwa perubahan terbanyak adalah perubahan secara negatif dengan jumlah negative ranks sebanyak 14 orang. Hal ini berarti informasi pembelajaran di kelas edukasi yang dirasa sulit oleh para istri/ anak disampaikan kepada suami/ ayah dan suami/ ayah ikut menerima keputusan istri/ anak.

Hasil evaluasi selama edukasi dapat dilihat pada tabel 4, terlihat partisipan mengakui bahwa cara penyampaian materi sudah cukup jelas, dan mereka banyak mendapatkan informasi baru yang bermanfaat, tetapi kebanyakan dari mereka tidak ingin melanjutkan pembelajaran ini, dikarenakan terlalu sulit dan tidak yakin apakah bisa menambah penghasilan secara ekonomi. Mengenai pemakaian alat K3 (pelindung diri), mereka mengatakan tidak terbiasa, agak merepotkan, dan tidak mempunyai uang untuk membeli alat pelindung diri saat bekerja. Untuk bertanam sayur/ pohon dalam wadah bekas, agak sulit dikarenakan lalat yang cukup banyak dan mematikan daun daun yang mulai tumbuh dan kualitas air dan tanah yang buruk. Untuk meneruskan pengelolaan sampah organik menjadi kompos juga belum memungkinkan, karena tidak terlalu yakin dengan nilai ekonomisnya.

Tabel 4. Jawaban Pertanyaan Angket Evaluasi Kegiatan Edukasi

\begin{tabular}{|c|c|c|c|}
\hline No & Pertanyaan & $\begin{array}{c}\text { Jumlah } \\
\text { Jawaban } \\
\text { Ya } \\
\end{array}$ & $\begin{array}{c}\text { Jumlah } \\
\text { Jawaban } \\
\text { Tidak } \\
\end{array}$ \\
\hline 1 & $\begin{array}{l}\text { Apakah menurut } \\
\text { Anda bahan yang } \\
\text { diberikan sudah } \\
\text { jelas dalam cara } \\
\text { penyampaianya? }\end{array}$ & 11 & 1 \\
\hline 2 & $\begin{array}{l}\text { Apakah dari } \\
\text { keseluruhan bahan } \\
\text { yang sudah } \\
\text { disampaikan } \\
\text { menarik bagi } \\
\text { Anda? }\end{array}$ & 12 & 0 \\
\hline 3 & $\begin{array}{l}\text { Apakah Anda } \\
\text { belajar banyak hal } \\
\text { baru dari bahan } \\
\text { yang disampaikan? }\end{array}$ & 11 & 1 \\
\hline 4 & $\begin{array}{l}\text { Menurut Anda } \\
\text { apakah dari } \\
\text { keseluruhan bahan } \\
\text { yang sudah } \\
\text { disampaikan } \\
\text { bermanfaat bagi } \\
\text { Anda? }\end{array}$ & 12 & 0 \\
\hline 5 & $\begin{array}{l}\text { Apakah dari bahan } \\
\text { yang membuat } \\
\text { Anda tertarik akan } \\
\text { Anda lanjutkan? }\end{array}$ & 4 & 8 \\
\hline
\end{tabular}

Tema edukasi yang menarik untuk partisipan dapat dilihat pada gambar 5, dimana tema 3 yaitu ketrampilan tangan daur ulang adalah yang paling menarik untuk partisipan. Saat kelas edukasi selesai sudah dihasilkan beberapa keranjang plastik belanja dengan kualitas yang cukup bagus. Semua hasil karya partisipan dalam kelas edukasi tersebut sudah dijual oleh BPM LDD KAJ. Tetapi dalam perjalanannya, saat meneruskan kegiatan diatas, biro merasa sulit untuk memasarkan kembali produk kerajinan daur ulang dari Bintara. 


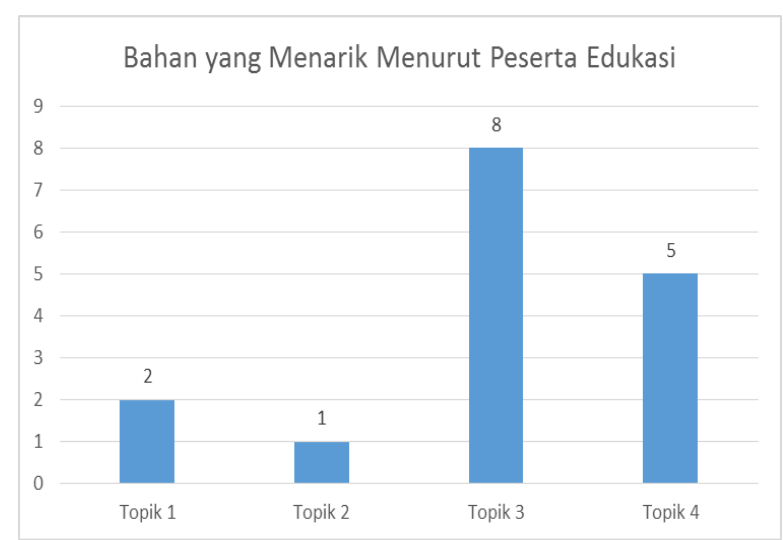

Gambar 5. Topik Edukasi yang Menarik Berdasarkan Angket Evaluasi

Penerapan ergonomi partisipasi untuk mengubah kualitas hidup keluarga pemulung/ tukang sampah, memerlukan kondisi tertentu supaya bisa berlangsung secara berhasil, yaitu : adanya waktu yang cukup untuk semua partisipan baik yang terlibat sebagai peserta ataupun relawan pengajar, perlu ikut terlibat dalam proses untuk menumbuhkan saling percaya, harus bisa meyakinkan partisipan bahwa manfaat yang diperoleh akan lebih besar dari pada biaya yang dikeluarkan, relevan dengan kebolehan partisipan yang dilatih, cukup waktu berkomunikasi dan cara berkomunikasi, tidak ada perasaan dipaksa oleh pihak lain dan masih berada dalam wilayah kebebasan bekerja mereka. Pada gambar 6 dan 7, terlihat partisipasi aktif dari para istri dan anak.

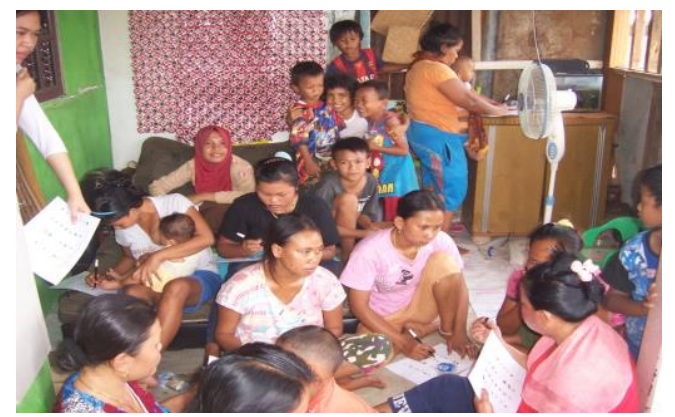

Gambar 6. Berdiskusi dan Memberikan Pendapat Mengenai Suatu Tema Edukasi (Partisipan Adalah Ibu Bos/ Kepala Lapak, Ibu Pekerja Tukang Sampah/ Pemulung

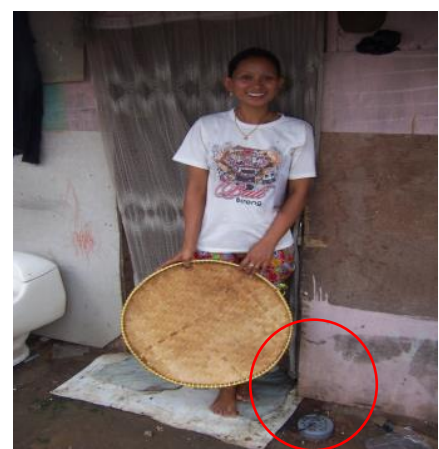

Gambar 7. Salah Satu Ibu Pemulung Mengerjakan Tugas Praktek Edukasi : Membuat Lubang Resapan Biopori

\section{Kesimpulan}

Penerapan ergonomi partisipasi di lapak sampah Bintara Bekasi, sudah dilakukan melibatkan partisipan keluarga pemulung/ tukang sampah, pengajar dari instansi pendidikan, pegiat lingkungan hidup dan bank sampah, serta lembaga sosial. Penerapan ini dapat dikatakan cukup berhasil karena para partisipan mau mengikuti proses edukasi dan mau terlibat dalam kegiatan, seperti pembuatan lubang resapan biopori, membuat komposter, membuat kerajinan tangan dari bahan bekas dan menggunakan wadah bekas sebagai media tanam. Penurunan nilai sikap niat dan perilaku dari warga lapak sampah (partisipan dan control grup) terhadap kegiatan edukasi yang diukur dengan menggunakan model theory of reasoned action, dapat dipengaruhi oleh proses edukasi yang telah dilakukan, karena dirasa sulit untuk mempraktekkannya dalam keseharian hidup, agak malas, merasa capek (karena kondisi udara lingkungan sekitar lapak sampah Bintara Bekasi yang memang membuat orang cepat lelah) dan butuh tenaga lebih untuk mewujudkan, serta tidak terlalu yakin dengan nilai ekonomis yang dihasilkan. Beberapa warga mempunyai latar belakang keluarga besar mereka adalah petani di Karawang dan Indramayu, dimana hidup sebagai petani garapan adalah sangat jauh lebih sulit mendapat penghasilan yang layak. Mereka mengatakan menjadi pemulung dan tukang sampah lebih berhasil secara ekonomis untuk kehidupan mereka, sehingga mereka tidak terlalu menginginkan kembali mengeluti pekerjaan mencari nafkah yang berhubungan dengan mengolah tanah dan tanaman.

Untuk kedepannya belum ada solusi yang bisa diusulkan, dikarenakan masalah ini adalah masalah kemanusiaan dan menyangkut moralitas, yang mana harus diupayakan solusinya oleh Pemerintah bekerjasama dengan instansi/ perusahaan pemberi dana CSR yang peduli akan nasib tukang sampah/ pemulung. Solusi saat ini yang dapat dilakukan oleh BPM adalah tetap memantau perkembangkan 
pengelolaan tabungan koperasi MISI SAMA yang sudah berjalan di lapak 1 Bintara.

\section{Ucapan Terima Kasih}

- Penelitian ini dibiayai LPPM Universitas Pelita Harapan.

- Penelitian ini didukung Biro Pelayanan Masyarakat (BPM) Lembaga Daya Dharma KAJ.

\section{Daftar Pustaka}

A.M. Sugeng Budiono. 2003. Bunga Rampai Hiperkes dan Kesehatan Kerja. Semarang : Badan Penerbit UNDIP.

Badan Standarisasi Nasional (BSN),Standar Nasional Indonesia, Tata Cara Teknik Operasional Pengelolaan Sampah Perkotaan, SNI 19-24542002

Berita Satu. "Pemkot Bekasi Gagas Emapt Program Konservasi Lingkungan," Berita Satu Online. Home page on-line. Available from http://www.beritasatu.com/megapolitan/378432pemkot-bekasi-gagas-empat-program-konservasilingkungan.html; Internet; akses 22 November 2016.

Clayton Susan dan Gene Myers, 2014, diterjemahkan oleh Daryatno, Psikologi Konservasi: Memahami dan Meningkatkan Kepedulian Manusia Terhadap Alam, cetakan 1, Penerbit Pustaka Pelajar.

Dharmmesta, Basu Swastha. 1998. Theory of Planned Behavior dalam Penelitian Sikap, Niat dan Perilaku Konsumen. Kelola 8 (7) : 85-113.

Gloss, David S., Wardle, Miriam Gayle, Introduction to Safety Engineering. Aegis. 1984.

Hignett Sue, Wilson John, Morris Wendy, Finding ergonomic solution- participatory approaches, Occupational Medicine 2005,55:200-207. http://occmed.oxfordjournals.org/content/55/3/20 0.full.pdf

Hoornweg Dabiel, and Perinaz Bhada Tata, What a waste, A Global Review of Solid Waste Management, March 2012, No 15, Urban Development \& Local Govenment Unit World Bank

Jakarta Forum. "Gandeng Dinas Kebersihan, KLHK Bina Pemulung di Jakarta dan Bekasi," Jakarta Forum Online. Home page on-line. Available from http://www.jakartaforum.co.id/2016/11/gandengdinas-kebersihan-klhk-bina.html; Internet; akses 22 November 2016.

Kompas. "Sampah Potensi Penggerak Roda Ekonomi," Kompas Online. Home page on-line. Available from http://print.kompas.com/baca/opini/dudukperkara/2016/05/12/Sampah-Potensi-Penggerak-
Roda-Ekonomi; Internet; accessed 22 November 2016.

USU. "Pengaruh LingkunganTempat Pembuangan Akhir Sampah, Personal Hygiene dan Indeks Masa Tubuh (IMT) Terhadap Keluhan Kesehatan Pada Pemulung di Keluarahan Terjun Kecamatan Medan Marelan," USU Online. Home page online. Avaible from http://repository.usu.ac.id/bitstre am/123456789/33879/1/Appendix.pdf; Internet; Accessed 2 September 2016.

Manuaba Adnyana, 23 November 1999, Penerapan Pendekatan Ergonomi Partisipasi Dalam Meningkatkan Kinerja Industri, Laboratorium Fisiologi Fakultas Kedokteran Program Pascasarjana Ergonomi, Universitas Udayana, Disampaikan dalam Seminar Nasional Ergonomi Reevaluasi Penerapan Ergonomi dalam Meningkatkan Kinerja Industri Surabaya.

Motamedzade M, Hoshang S, Anoushiravan K, Adel A, 2003, The Impact of Participatory Ergonomics on Working Conditions, Quality, and Productivity, International Journal of Occupational Safety and Ergonomics, Vol 9, No 2, 135-147

OGP, Guidelines for Waste Management with Special Focus on Areas With Limited Infrastructure, report No 413,September 2008

Ridley, John, Astranto, Soni [Trans.], Ikhtisar kesehatan dan keselamatan kerja, 3rd Ed.. Erlangga. 2008.

Vink, P.; Koningsveld, E.A. and Molenbroek, J.F. 2006. Positive outcomes of participatory ergonomics in terms of greater comfort and higher productivity. Journal of Applied Ergonomics, 37: 537-546.

Vink, P.; Imada, A.S. and Zink, K.J. 2008. Defining stakeholder involvement in participatory design processes. Journal of Applied Ergonomics, 39: 519-526.

Zubaedi, Pengembangan Masyarakat Wacana dan Praktik, 2013, Kencana Prenada Media Group. Badan Standarisasi Nasional (BSN),Standar Nasional Indonesia, Pengelolaan Sampah di Pemukiman, SNI 32742:2008 